\title{
Bioactive Secondary Metabolites from Trichoderma spp. against Phytopathogenic Bacteria and Root-Knot Nematode
}

\author{
Raja Asad Ali Khan $\mathbb{D}$, Saba Najeeb, Zhenchuan Mao, Jian Ling, Yuhong Yang, Yan Li *D \\ and Bingyan Xie * \\ Institute of Vegetables and Flowers, Chinese Academy of Agricultural Sciences, Beijing 100081, China; \\ asadraja@aup.edu.pk (R.A.A.K.); sabanajeeb831@gmail.com (S.N.); maozhenchuan@caas.cn (Z.M.); \\ lingjian2005@126.com (J.L.); yangyuhong@caas.cn (Y.Y.) \\ * Correspondence: liyan05@caas.cn (Y.L.); xiebingyan@caas.cn (B.X.)
}

\begin{abstract}
Losses in crops caused by plant pathogenic bacteria and parasitic nematode are increasing because of a decrease in efficacy of traditional management measures. There is an urgent need to develop nonchemical and ecofriendly based management to control plant diseases. A potential approach of controlling plant disease in the crops is the use of biocontrol agents and their secondary metabolites (SMs). Luckily fungi and especially the genus Trichoderma comprise a great number of fungal strains that are the potential producer of bioactive secondary metabolites. In this study secondary metabolites from ten Trichoderma spp. were evaluated for their antibacterial and nematicidal potential against phytopathogenic bacteria Ralstonia solanacearum, Xanthomonas compestris and plant parasitic nematode Meloidogyne incognita. Five different growth media were evaluated for the production of SMs. It was shown that SMs of different Trichoderma spp. obtained on different growth media were different in the degree of their bioactivity. Comparison of five growth media showed that SMs produced on solid wheat and STP media gave higher antibacterial activity. SMs of T. pseudoharzianum (T113) obtained on solid wheat media were more effective against the studied bacteria followed by SMs from T. asperelloides (T136), T. pseudoharzianum (T129) and T. pseudoharzianum (T160). Scanning electron microscopy (SEM) was further conducted to observe the effect of SMs on bacterial cell morphology. As evident from the SEM, SMs produced severe morphological changes, such as rupturing of the bacterial cell walls, disintegration of cell membrane and cell content leaking out. SMs from T. viridae obtained on liquid STP and solid wheat media showed the highest percent of M. incognita juveniles (J2s) mortality and inhibition in egg hatching of M. incognita. The results of our study suggest that T. pseudoharzianum (T113) and T. viridae could be selected as an effective candidate for SMs source against phytopathogenic bacteria and M. incognita respectively.
\end{abstract}

Keywords: secondary metabolites; Trichoderma spp.; phytopathogenic bacteria; root-knot nematode

\section{Introduction}

Both biotic and abiotic agents cause diseases in plants and pose a problem in agriculture by significantly affecting plant growth and crop yield at a global scale [1,2]. It is estimated that $10 \%$ of global food production losses are because of plant pathogens [3]. The main plant pathogens are viruses, oomycetes, fungi, bacteria and nematodes. Among the latter, there are more than 200 phytopathogenic bacterial species [4], the most important of which are Agrobacterium, Pseudomonas, Pectobacterium, Xylella, Erwinia, Ralstonia, Dickeya and Xanthomonas [5]. Ralstonia solanacearum, a species of the genus Ralstonia, is a gram-negative bacterium and is considered to be one of the most devastating plant 
pathogens. It has a global distribution and has a significant economic impact worldwide [6]. Another bacterium Xathomonas campestres, a member of genus Xanthomonas, is the pathogen of tomato and pepper bacterial spots, which reportedly cause $50 \%$ yield losses for tomatoes in many countries around the world $[7,8]$. In addition to bacterial disease, plant parasitic nematodes are also becoming a limiting factor in the successful cultivation of agricultural crops, causing an annual yield loss estimated at 8.8-14.6\% of total crop production [9]. Root-knot nematodes (RKNs; Meloidogyne spp.) constitute major pests in agriculture worldwide, causing annual economic losses estimated at about $\$ 118$ billion [10]. M. incognita, infecting the roots of almost all cultivated plants, is one of the most important RKN species. RKNs cause the formation of giant cells in the roots of plants, prevent the absorption of water and nutrients and promote the infection of pathogenic microorganisms [11].

Control of plant bacterial pathogens involves chemical control with streptomycin or copper and use of resistant varieties [12,13]. However, the use of resistant varieties has not always been successful, showing a negative correlation between resistance and yield $[14,15]$. The resistance of these varieties is often strain-specific and bacteria develop resistance to the chemicals [16,17]. In the case of RKNs, the high reproduction rate and short generation time make it difficult to control $[18,19]$. Chemical nematicides are usually used. Although chemical nematicides have shown good control on plant-parasitic nematodes, the public concern over the chemical nematicides is not only their toxicity but also their loss of efficiency after prolonged use [20,21]. Policies aimed at supporting environmentally friendly or sustainable agricultural practices in many countries and the increasing demand for environmental protection measures require the development of safe and effective alternatives [22]. A potential environmental and consumer-friendly opportunity to control plant diseases in crops is the use of biocontrol agents and their secondary metabolites [23].

Secondary metabolites (SMs) are small molecules that are not directly essential for growth [24-26]. These SMs also have an antimicrobial role against agriculturally important phytopathogens [27]. Among microorganisms, fungi are unique in SMs production, producing a vast range of SMs that are known for their capacities to secrete high levels of enzymes, antibiotics, vitamins, polysaccharides and organic acids [28]. Among fungi, the genus Trichoderma contains some of the most potent biocontrol agents in use today $[29,30]$. SMs produced by Trichoderma spp. can be used in medical, agricultural and industrial fields and are therefore vital to humans. These metabolites such as gliotoxin, peptaibols, gliovirin, terpenes, polyketides, and pyrones exhibit bioactivity against many phytopathogenic yeasts, filamentous fungi and bacteria [31-33].

The antibiotic production ability of the microorganism is generally species/isolate dependent. A given Trichoderma species can produce several antibiotic compounds and, in a similar way, a given antibiotic can be produced by different Trichoderma species [34]. Moreover, different isolates of the same species can produce different compounds [35]. Evaluating large numbers of fungal strains for antimicrobial properties in greenhouse studies on plants can be restrictively labor intensive and time-consuming. For the selection of bio-control antagonists, in vitro assays are used to demonstrate the mechanism of action of an antagonist [36]. It is the first step in the selection of effective candidates and cannot be ignored [37-39]. In addition, in vitro assessment to screen fungal spp. for their ability to produce bioactive compounds would facilitate the selection of the required candidate to evaluate in greater detail. Such an approach has been used successfully with other microbial organisms. For example, the efficiency of an investigation was increased for rhizobacterial strains to evaluate as control agents of M. incognita by first selecting those strains that produced nematicidal compounds in vitro [40]. The aim of this work was the evaluation of secondary metabolites of different Trichoderma spp. against plant pathogenic bacteria and parasitic nematodes. As the ability of a microorganism to produce metabolites is directly related to the type of substrate used for its growth [34], the study was also extended to investigate different growth media for the production of anti-bacterial and nematicidal SMs by Trichoderma spp. Moreover, a scanning electron microscopy (SEM) study was also conducted to observe the antimicrobial effect of SMs on bacterial morphology. 


\section{Materials and Methods}

\subsection{Fungal, Bacterial Cultures and Nematode Inoculum}

Pre-identified and $-80{ }^{\circ} \mathrm{C}$-preserved pure cultures of ten Trichoderma strains including T. pseudoharzianum (T113), T. koningiopsis (T84), T. asperelloides (T136), T. pseudoharzianum (T129), T. pseudoharzianum (T160), T. afroharzianum (32233), T. acitrinoviride (T130), T. longibrachiatum (T161), T. afroharzianum (T52), T. viridescens (T196) and phytopathogenic bacteria R. solanacearum and $X$. compestris were obtained from the Agricultural Culture Collection of China (ACCC) and the Institute of Vegetables and Flowers, Chinese Academy of Agricultural Sciences (Beijing, China). Fungal cultures were grown on potato dextrose agar (PDA) media at $28{ }^{\circ} \mathrm{C}$ for $5-7$ days [41] while bacterial cultures were grown on LB media at $28^{\circ} \mathrm{C}$ for $24-48 \mathrm{~h}$.

For nematode inoculum, pre-identified and pre-established egg masses of $M$. incognita were obtained from pepper plants (Capsicum annuum cv. Qiemen) in the greenhouses of the Institute of Vegetables and Flowers, Chinese Academy of Agricultural Sciences (Beijing, China). The egg masses were sterilized with $0.5 \%$ sodium hypochlorite $(\mathrm{NaClO})$ for $1 \mathrm{~min}$ and washed with sterile water three times, then immersed in a Petri dish with $20 \mathrm{~mL}$ of sterile water at $28^{\circ} \mathrm{C}$ [42]. The second-stage M. incognita juveniles (J2s) were collected after $24 \mathrm{~h}$. Multiplication of egg masses was done by inoculating new pepper seedlings of the same cultivar with freshly hatched J2s. Both eggs and J2s were stored in $1 \%$ saline at $4{ }^{\circ} \mathrm{C}$ or immediately used in bioassays [42].

\subsection{Extraction of Fungal Metabolites}

For the extraction of secondary metabolites (SMs), five plugs of freshly prepared Trichoderma culture were inoculated into a $500 \mathrm{~mL}$ flask containing $100 \mathrm{~mL}$ of seed media having a composition of bacto neopeptone $10 \mathrm{~g}$, maltose $40 \mathrm{~g}$, yeast extract $10 \mathrm{~g}$ and agar $4 \mathrm{~g} / \mathrm{L}$. The flasks were incubated in the shaker at $220 \mathrm{RPM}$ and $25^{\circ} \mathrm{C}$ for 4 days. After 4 days of incubation, four liquid media (100 mL/flask) and one solid media (Table S1) in separate $500 \mathrm{~mL}$ flasks were inoculated with seed media of fungus at the rate of $5 \mathrm{~mL}$ per flask. The solid medium kept stationary at $25^{\circ} \mathrm{C}$ while four liquid media were incubated in a shaker at $220 \mathrm{RPM}$ and $25^{\circ} \mathrm{C}$ for two weeks. After incubation, the flasks were poured with ethyl acetate (150 mL/flask), incubated at $25^{\circ} \mathrm{C}$ at $120 \mathrm{RPM}$ for $2 \mathrm{~h}$ and kept stationary for $30 \mathrm{~min}$. The ethyl acetate layer having SMs was separated and metabolites were obtained after removing the solvent (ethyl acetate) under reduced pressure [41]. The metabolites were dried, stored at $4{ }^{\circ} \mathrm{C}$ and tested for their anti-bacterial and nematicidal activities.

\subsection{Evaluation of Anti-Bacterial Activity}

The antibacterial activity of SMs obtained on five different growth media were examined against two plant pathogenic bacteria, $R$. solanacearum and $X$. compestris, by the agar well diffusion and disk diffusion method [43]. The dried fungal metabolites were dissolved in methanol at the concentration of $150 \mathrm{mg} / \mathrm{mL}$ and used for antibacterial activity. At first, $25 \mathrm{~mL}$ LB medium containing $0.5 \mathrm{~mL}$ bacterial suspension (108 cfu) was poured in each plate and allowed to cool. Using sterilized $2 \mathrm{~mm}$ diameter borer, a total of seven wells were punched in each plate. Five wells each were poured with $10 \mu \mathrm{L}$ of fungal metabolites obtaining five different growth media (STP, MMK2, SOLID, MOF and SuM), one well with $10 \mu \mathrm{L}$ of methanol (negative control) and one with $10 \mu \mathrm{L}$ of ampicillin $4 \mathrm{mg} / \mathrm{mL}$ (positive control). In the case of the disc diffusion method, discs were utilized instead of wells. Ten $\mu \mathrm{L}$ of fungal metabolites was poured on sterile paper discs of $5 \mathrm{~mm}$ in diameter and deposited on the LB medium plates inoculated with bacteria. The plates were incubated at $28{ }^{\circ} \mathrm{C}$ for $24 \mathrm{~h}$. Antibacterial activity was estimated by the size (diameter in $\mathrm{mm}$ ) of growth inhibition zones [44].

\subsection{SEM Studies}

To confirm the effect of the SMs on the in-vitro growth inhibition of the bacterial pathogen and to observe any morphological alterations occurring in the bacterial cells as a result of SMs treatment, 
scanning electron microscope (JSM5910, JEOL, Japan) was used. To prepare control and treated cells for morphological observations, small agar pieces were cut out from the relevant inhibition zones, fixed in $2.5 \%(v / v)$ glutaraldehyde (in phosphate buffer; $\mathrm{pH} 7.2)$ for $1 \mathrm{~h}$ at $40{ }^{\circ} \mathrm{C}$. The pieces were then washed three times with phosphate buffer for $10 \mathrm{~min}$ and fixed for $2 \mathrm{~h}$ with $1 \%(w / v)$ osmium tetroxide $\left(\mathrm{OSO}_{4}\right)$. This was followed by three washings (in phosphate buffer) for $10 \mathrm{~min}$ and dehydration in a graded ethanol series (30\%, 50\%, 70\%, 90\%, and 95\%) for $15 \mathrm{~min}$ each. To achieve the critical point, the samples were then subjected to $100 \%$ ethanol and $\mathrm{CO}_{2}$. The totally dried samples were then coated with gold ion and submitted for SEM analysis [45].

\subsection{Evaluation of Nematicidal Activity}

Anti-nematode activity was demonstrated in two separate simultaneous experiments on eggs and J2s of M. incognita. Fungal SMs were dissolved in methanol to get the concentration of $200 \mathrm{mg} / \mathrm{mL}$. Briefly, J2s (100) and eggs (150) of M. incognita contained in $100 \mu \mathrm{L}$ of water were exposed to SMs in micro well bioassay experiments ( 24 well microwell plates, Sigma-Aldrich, USA). Each well was loaded with $100 \mu \mathrm{L}$ of distilled water containing J2s (100) and eggs (150) of M. incognita separately, $390 \mu \mathrm{L}$ of distilled water and $10 \mu \mathrm{l}$ of fungal SMs $(200 \mathrm{mg} / \mathrm{mL})$. For evaluating the effect of the solvent, methanol was also used as one of the treatments. Wells containing only sterile distilled water (SDW) in place of fungal SMs served as negative control while $10 \mu \mathrm{g} / \mathrm{mL}$ Abamectin-loaded wells were served as positive controls. Each treatment was replicated three times and the experiment was repeated once in a completely randomized design [46]. Microwell plates were incubated in the dark at $27^{\circ} \mathrm{C}$ and data on the percent of J2s mortality were recorded after incubating for 24,48 and $72 \mathrm{~h}$. J2s were defined as dead when they showed no movement and adopted straight shape despite physical stimulation with a fine needle [47]. Abbott's formula was used for the calculation of mortality rates (M) [48] as described in Equation (1):

$$
\mathrm{M}=[(\mathrm{Mt}-\mathrm{Mc}) /(100-\mathrm{Mc})] \times 100
$$

where Mt presents the percent of mortality in treatment and Mc presents the percent of mortality in control.

Inhibition of egg hatching was assessed under a light microscope at seven days after treatment. Hatch inhibition (HI) was calculated by using the formula described in Equation (2):

$$
\mathrm{HI}=[(\mathrm{C}-\mathrm{T}) / \mathrm{C}] \times 100
$$

where $C$ presents the percent of eggs hatched in the control and $T$ presents the percent of eggs hatched in the treatment.

\subsection{Statistical Analysis}

Each treatment was replicated three times and results of the data are presented as mean value \pm SD. Recorded data were analyzed by analysis of variance (ANOVA) using "Statistix" (Analytical Software, version 8.0, USA) and treatment means were compared using Fisher's Protected LSD test at $p=0.05[46]$.

\section{Results}

\subsection{Antibacterial Effect of SMs from Trichoderma spp. Produced on Different Growth Media}

Trichoderma secondary metabolites (SMs) obtained on different growth media showed significantly different results regarding bioactivity against two studied phytopathogenic bacteria. After control (ampicillin), SMs from T. pseudoharzianum (T113) exhibited maximum antibacterial activity compared to other strains, followed by T. asperelloides (T136), T. pseudoharzianum (T129) and T. pseudoharzianum (T160) (Tables 1 and 2). The inhibition zones recorded for T. pseudoharzianum (T113) were $21.8 \mathrm{~mm}$ and $21.3 \mathrm{~mm}$ (solid media) for $R$. solanacearum and X. compestris, respectively, through the well diffusion method 
(Figure 1: A1,2). Similar results were seen when bioactivity was checked through the disc diffusion method, where SMs of T. pseudoharzianum (T113) produced an inhibition zone of 20.0 and $20.4 \mathrm{~mm}$ against $R$. solanacearum and X. compestris through the disc diffusion method (Figure 1: B1,2). The SMs of T. asperelloides (T136), T. pseudoharzianum (T129) and T. pseudoharzianum (T160) showed inhibition zones of $15.1,14.2,15.3 \mathrm{~mm}$ against $R$. solanacearum and 14.8,15.2, $15.5 \mathrm{~mm}$ against $X$. compestris through the well diffusion method (Tables 1 and 2). The disc diffusion method of these three strains also gave similar activity (Figure 2). Metabolites from other strains either exhibited very little bioactivity or showed no activity. The positive control ampicillin gave the highest value for the zone of inhibition while the negative control methanol did not affect the bacterial growth.
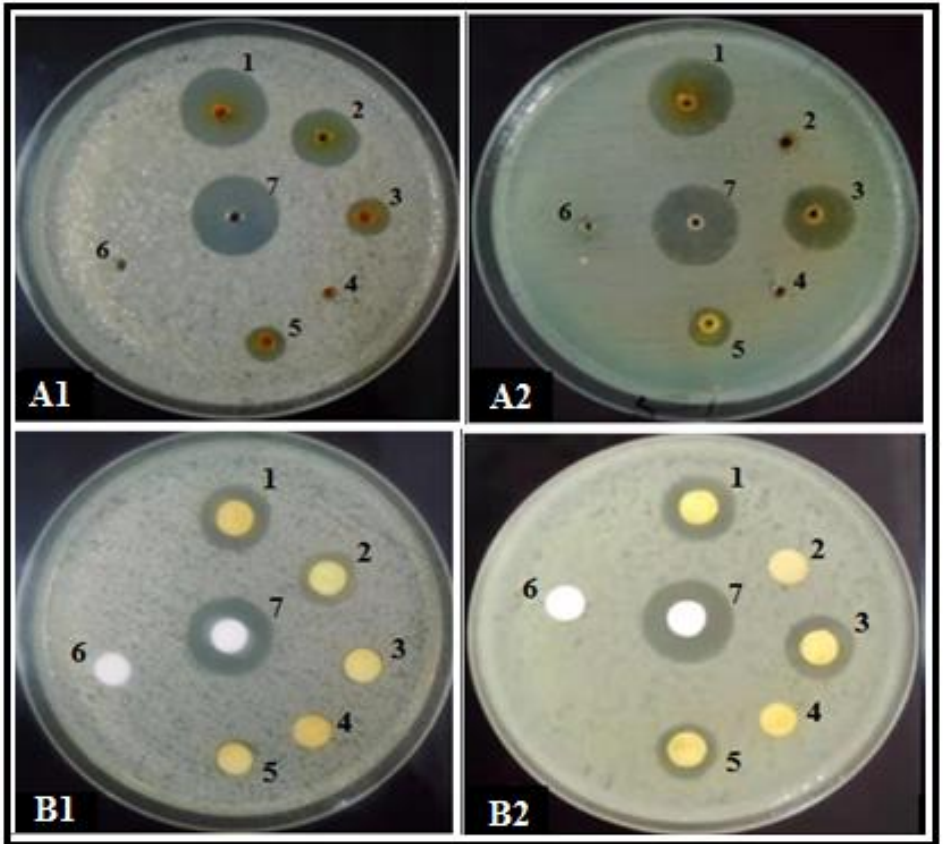

Figure 1. Zone of bacterial growth inhibition $(\mathrm{mm})$ produced by secondary metabolites (SMs) of T. pseudoharzianum (T113) obtained on different growth media (1) Solid; (2) STP; (3) MOF; (4) MMK2; (5) SuM; (6) negative control, methanol; (7) positive control, ampicillin; (A) well diffusion method: (A1) R. solanacearum; (A2) X. compestris; (B) disc diffusion method: (B1) R. solanacearum; (B2) X. compestris.

Table 1. Growth inhibition ( $\mathrm{mm}$ ) of $R$. solanacearum affected by SMs (obtained on different growth media) of Trichoderma spp. evaluated through the well diffusion method.

\begin{tabular}{|c|c|c|c|c|c|c|c|}
\hline Trichoderma spp. & \multicolumn{5}{|c|}{ Growth Media } & \multicolumn{2}{|c|}{ Control } \\
\hline T. pseudoharzianum (T113) & $21.8 \pm 0.4^{\mathrm{a}}$ & $14.3 \pm 0.4^{c}$ & $12.2 \pm 0.8^{\mathrm{d}}$ & $0.0^{\mathrm{s}}$ & $9.0 \pm 0.9^{\text {hij }}$ & $22.3 \pm 0.5^{\mathrm{a}}$ & $0.0^{\mathrm{s}}$ \\
\hline T. koningiopsis (T84) & $9.7 \pm 0.5^{\text {gh }}$ & $7.1 \pm 0.3^{\mathrm{m}}$ & $8.4 \pm 0.2^{\mathrm{ijk}}$ & $0.0^{\mathrm{s}}$ & $4.2 \pm 0.1^{\mathrm{qr}}$ & $22.0 \pm 0.5^{\mathrm{a}}$ & $0.0^{\mathrm{s}}$ \\
\hline T. asperelloides (T136) & $15.1 \pm 0.2^{\mathrm{bc}}$ & $0.0^{\mathrm{s}}$ & $7.0 \pm 0.4^{\mathrm{mn}}$ & $0.0^{\mathrm{s}}$ & $7.8 \pm 0.1^{\mathrm{klm}}$ & $22.2 \pm 0.3^{\mathrm{a}}$ & $0.0^{\mathrm{s}}$ \\
\hline T. afroharzianum (32233) & $0.0^{\mathrm{s}}$ & $0.0^{\mathrm{s}}$ & $0.0^{\mathrm{s}}$ & $0.0^{\mathrm{s}}$ & $0.0^{\mathrm{s}}$ & $21.8 \pm 0.3^{\mathrm{a}}$ & $0.0^{\mathrm{s}}$ \\
\hline T. acitrinoviride (T130) & $8.2 \pm 0.1^{j \mathrm{kl}}$ & $5.2 \pm 0.2^{\mathrm{op}}$ & $7.0 \pm 0.0^{\mathrm{mn}}$ & $0.0^{\mathrm{s}}$ & $7.3 \pm 0.5^{\operatorname{lm}}$ & $22.3 \pm 0.2^{\mathrm{a}}$ & $0.0^{\mathrm{s}}$ \\
\hline T. hamatum (T21) & $5.2 \pm 0.2^{\mathrm{op}}$ & $4.5 \pm 0.1^{p q}$ & $6.1 \pm 0.2^{\text {no }}$ & $0.0^{\mathrm{s}}$ & $3.3 \pm 0.1^{\mathrm{r}}$ & $22.5 \pm 0.1^{\mathrm{a}}$ & $0.0^{\mathrm{s}}$ \\
\hline
\end{tabular}

Values are the mean of three replicates \pm SD (Standard deviation). Those mean values having the same lettering in a row or column are statistically not significant $(p \leq 0.05)$ from each other (Fisher's protected LSD test). LSD $=0.92$ in Fisher's protected LSD test. 
Table 2. Growth inhibition (mm) of X. compestris affected by SMs (obtained on different growth media) of Trichoderma spp. evaluated through the well diffusion method.

\begin{tabular}{|c|c|c|c|c|c|c|c|}
\hline \multirow{2}{*}{ Trichoderma spp. } & \multicolumn{5}{|c|}{ Growth Media } & \multicolumn{2}{|c|}{ Control } \\
\hline & Solid & STP & MOF & MMK2 & SuM & Ampicillin & Methanol \\
\hline T. pseudoharzianum (T113) & $21.3 \pm 0.1^{\mathrm{b}}$ & $0.0^{\mathrm{n}}$ & $16.8 \pm 0.2^{\mathrm{c}}$ & $0.0^{\mathrm{n}}$ & $10.3 \pm 0.5^{\mathrm{e}}$ & $21.9 \pm 0.5^{\mathrm{ab}}$ & $0.0^{\mathrm{n}}$ \\
\hline T. koningiopsis (T84) & $7.8 \pm 0.3^{\text {gh }}$ & $7.1 \pm 0.1^{\mathrm{ij}}$ & $9.5 \pm 0.1^{\mathrm{f}}$ & $0.0^{\mathrm{n}}$ & $4.5 \pm 0.2^{\mathrm{m}}$ & $22.2 \pm 0.1^{\mathrm{a}}$ & $0.0^{\mathrm{n}}$ \\
\hline T. asperelloides (T136) & $14.8 \pm 0.3^{\mathrm{d}}$ & $0.0^{\mathrm{n}}$ & $7.1 \pm 0.1^{\mathrm{ij}}$ & $0.0^{\mathrm{n}}$ & $6.2 \pm 0.4^{\mathrm{k}}$ & $21.7 \pm 0.4^{\mathrm{ab}}$ & $0.0^{\mathrm{n}}$ \\
\hline T. pseudoharzianum (T129) & $15.2 \pm 0.2^{\mathrm{d}}$ & $0.0^{\mathrm{n}}$ & $9.2 \pm 0.1^{\mathrm{f}}$ & $0.0^{\mathrm{n}}$ & $6.4 \pm 0.1^{\mathrm{k}}$ & $21.7 \pm 0.2^{\mathrm{ab}}$ & $0.0^{\mathrm{n}}$ \\
\hline T. pseudoharzianum (T160) & $15.5 \pm 0.2^{\mathrm{d}}$ & $9.7 \pm 0.1^{\text {ef }}$ & $0.0^{\mathrm{n}}$ & $7.4 \pm 0.2^{\mathrm{hi}}$ & $5.2 \pm 0.2^{1 \mathrm{~m}}$ & $22.3 \pm 0.1^{\mathrm{a}}$ & $0.0^{\mathrm{n}}$ \\
\hline T. afroharzianum (32233) & $0.0^{\mathrm{n}}$ & $0.0^{\mathrm{n}}$ & $0.0^{\mathrm{n}}$ & $0.0^{\mathrm{n}}$ & $0.0^{\mathrm{n}}$ & $21.8 \pm 0.4^{\mathrm{ab}}$ & $0.0^{\mathrm{n}}$ \\
\hline T. acitrinoviride (T130) & $9.5 \pm 0.2^{\mathrm{f}}$ & $4.9 \pm 0.1^{1 \mathrm{~m}}$ & $6.5 \pm 0.2^{\mathrm{j}^{\mathrm{k}}}$ & $0.0^{\mathrm{n}}$ & $9.3 \pm 0.1^{\mathrm{f}}$ & $22.0 \pm 0.4^{\mathrm{a}}$ & $0.0^{\mathrm{n}}$ \\
\hline T. hamatum (T21) & $5.2 \pm 0.1^{\operatorname{lm}}$ & $4.8 \pm 0.1^{\mathrm{m}}$ & $5.5 \pm 0.1^{1}$ & $0.0^{\mathrm{n}}$ & $4.9 \pm 0.3^{\mathrm{lm}}$ & $22.2 \pm 0.1^{\mathrm{a}}$ & $0.0^{\mathrm{n}}$ \\
\hline T. afroharzianum (T52) & $0.0^{\mathrm{n}}$ & $0.0^{\mathrm{n}}$ & $0.0^{\mathrm{n}}$ & $0.0^{\mathrm{n}}$ & $0.0^{\mathrm{n}}$ & $21.8 \pm 0.4^{\mathrm{ab}}$ & $0.0^{\mathrm{n}}$ \\
\hline T. viridae & $8.4 \pm 0.2^{g}$ & $9.5 \pm 0.1^{f}$ & $0.0^{\mathrm{n}}$ & $0.0^{\mathrm{n}}$ & $4.9 \pm 0.3^{\mathrm{lm}}$ & $22.1 \pm 0.2^{\mathrm{a}}$ & $0.0^{\mathrm{n}}$ \\
\hline
\end{tabular}

Values are the mean of three replicates \pm SD (Standard deviation). Those mean values having the same lettering in a row or column are statistically not significant $(p \leq 0.05)$ from each other (Fisher's protected LSD test). LSD $=0.67$ in Fisher's protected LSD test.

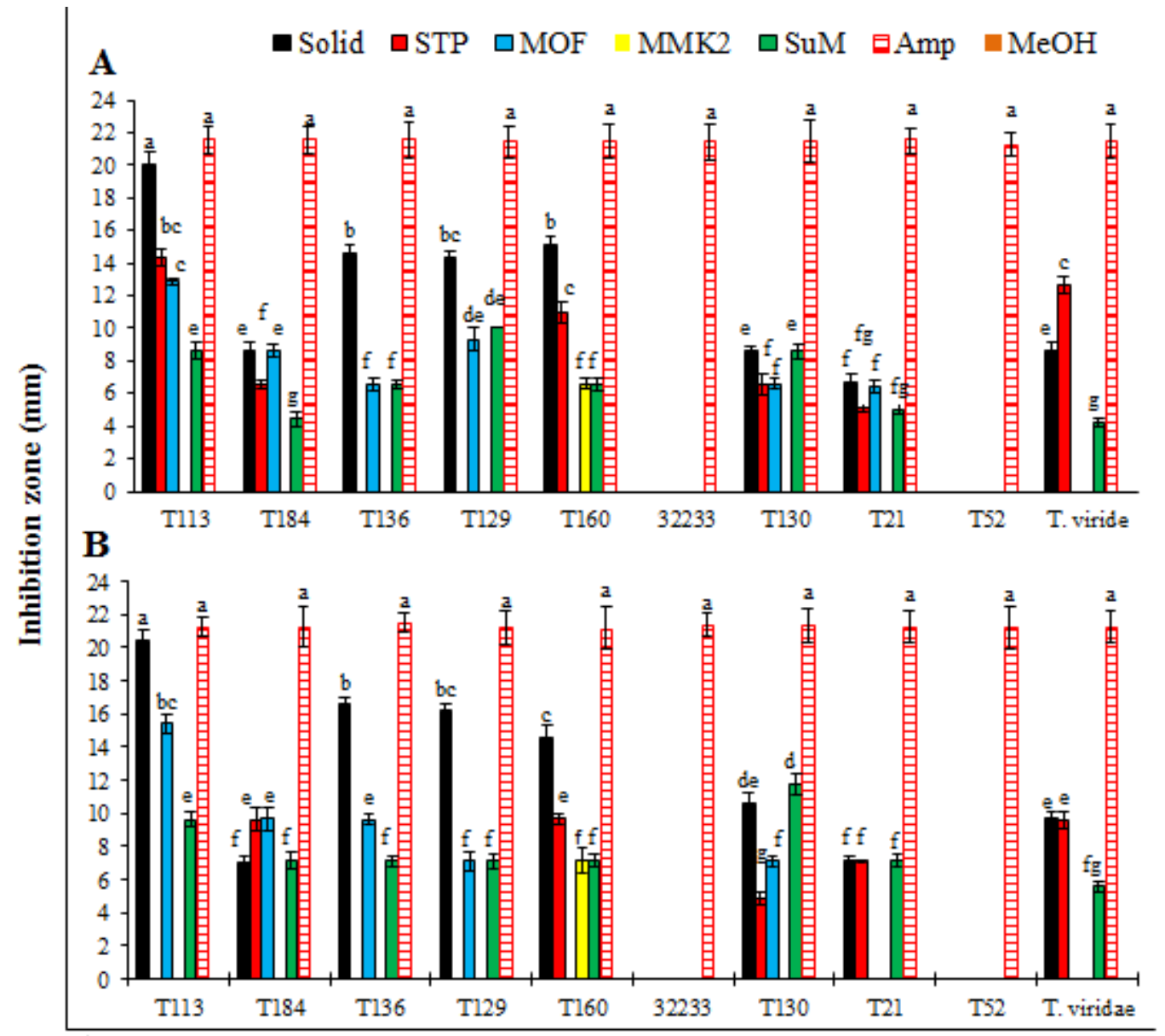

Trichoderma spp.

Figure 2. Growth inhibition ( $\mathrm{mm}$ ) of bacteria affected by SMs (obtained on different growth media) of Trichoderma spp. evaluated through the disc diffusion method. (A) Growth inhibition of R. solanacearum; (B) growth inhibition of $X$. compestris. Each value is a mean of three replicates. The bar represents the mean with standard deviation. Missing columns for some treatments indicated their $0.0 \mathrm{~mm}$ growth inhibition (or no activity). Treatments having similar lettering on the bar cha show no significant $(p \geq 0.05)$ difference according to Fisher's protected LSD test. 


\subsection{SEM Observations of the Bacterial Cells}

In order to observe the effect of SMs on morphological changes of bacterial cells, the most effective SMs (T. pseudoharzianum T113) treated bacterial cells and untreated bacterial cells were subjected to SEM study. SEM micrographs of treated bacteria and without treatment are illustrated in Figure 3. Cell wall degradation and morphology revealed that the bacterium was exposed to treatment and was absolutely different from the control (untreated). The characteristic morphology of the control group displayed a uniform rod-shaped surface of $R$. solanacearum (Figure 3a1) and X. compestris (Figure 3b1) while SM-treated cells showed enormous morphological alterations both in $R$. solanacearum (Figure 3a2) and X. compestris (Figure 3b2). Under the influence of SMs the bacterial cells seem misshaped, their cell wall degraded, the cell membranes disintegrated and cell contents leaked out.
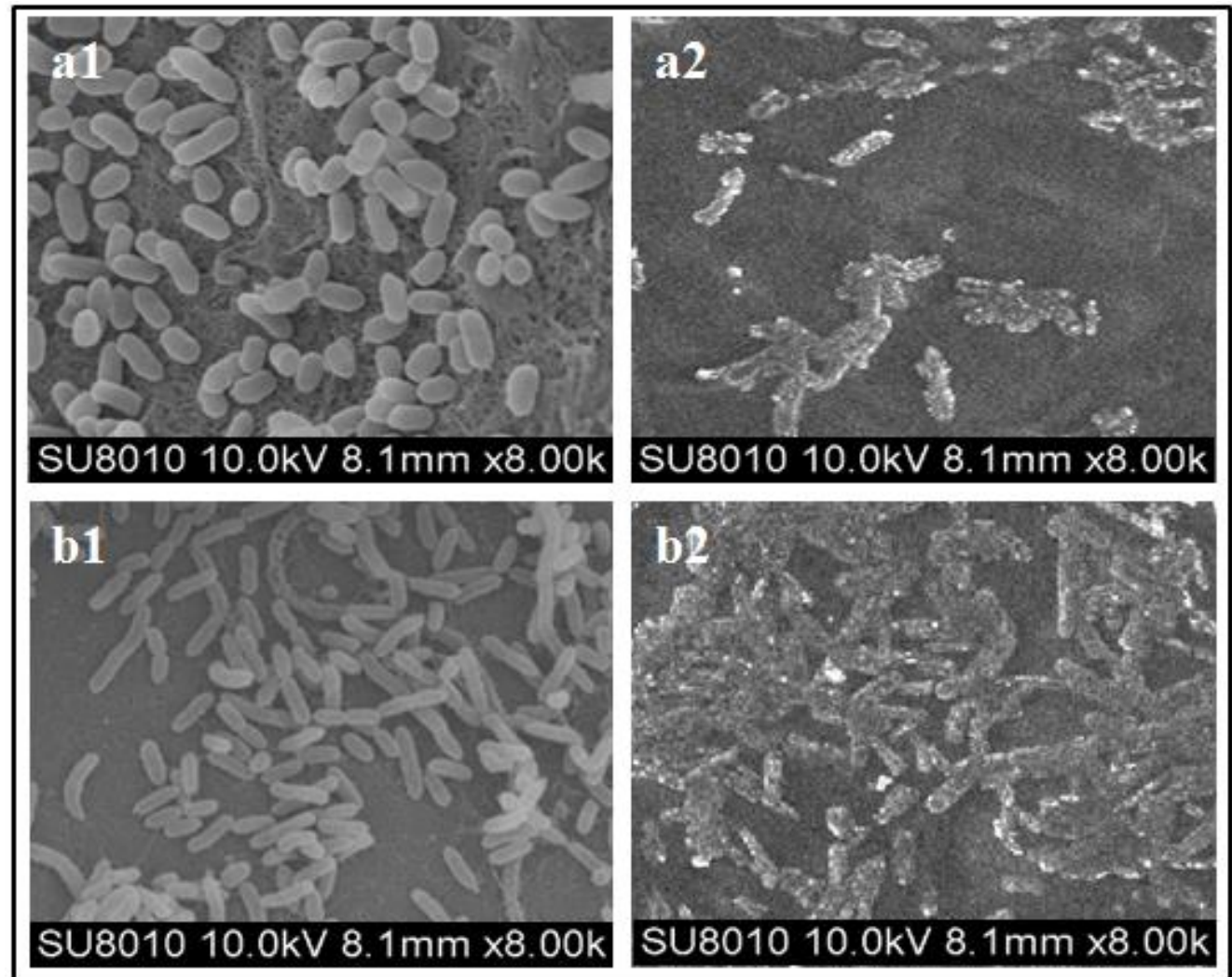

Figure 3. SEM micrograph of (a1) untreated normal $R$. solanacearum cells; (a2) treated $R$. solanacearum cells with SMs of T. pseudoharzianum (T113) obtained solid media; (b1) untreated normal X. compestris cells; (b2) treated X. compestris cells with T. pseudoharzianum (T113).

\subsection{Nematicidal Effect of SMs of Trichoderma spp. against Meloidogyne Incognita}

Results of nematicidal activity of SMs revealed that only SMs of T. viridae and T. hamatum (T21) effectively inhibited the hatching of M. incognita eggs. Among Trichoderma spp. the highest egg hatch inhibition (71.6\%) was achieved by SMs of T. viridae obtained on STP media followed by $67.3 \%$ of solid media (Figure 4). The second effective egg hatch inhibition of $59.2 \%$ and $54.7 \%$ was recorded with SMs of T. hamatum (T21) obtained on STP and solid media, respectively. Results of remaining tested Trichoderma spp. were not effective, showing very little or no effect (Figure 4). A similar trend was observed in the case of percent of juvenile mortality. After positive control the highest percent juvenile mortality was achieved by T. viridae on STP and solid media, respectively (Figure 5), followed by T. hamatum (T21). SMs from remaining Trichoderma spp. had little effect or were not effective (Figure 5). 


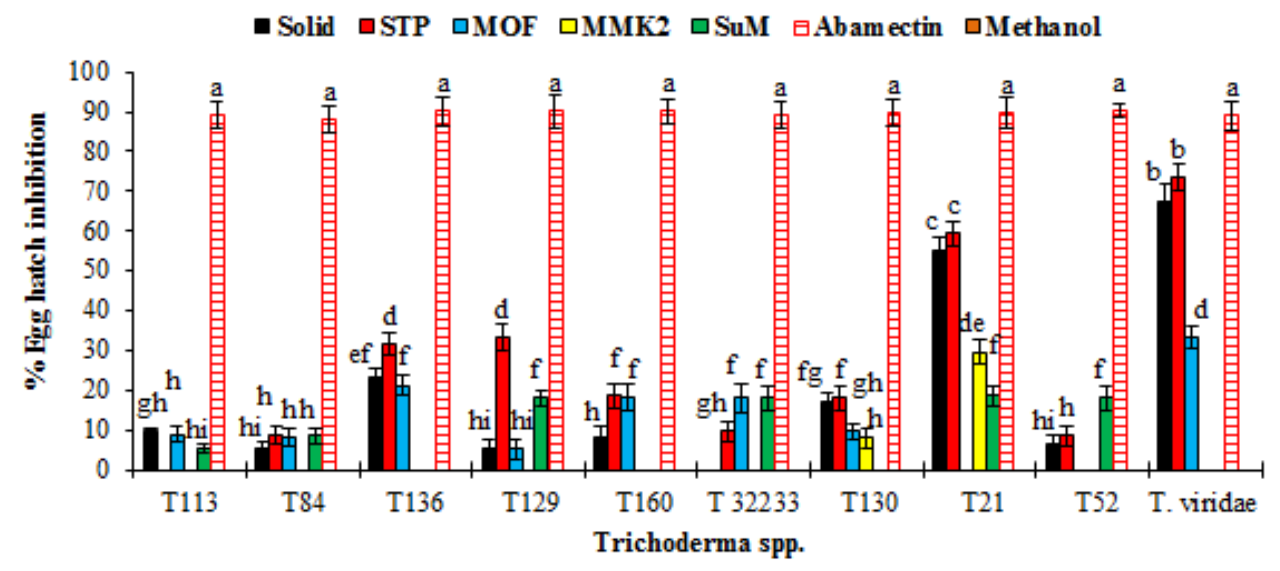

Figure 4. Effect of SMs of Trichoderma spp. obtained on different growth media on egg hatching of M. incognita. Values are the mean of three replicates. The bar represents the mean with standard deviation. Missing columns for some treatments indicated their $0.0 \%$ egg hatch inhibition (or no activity). Treatments having similar lettering on the bar chart show no significant $(p \geq 0.05)$ difference according to Fisher's protected LSD test.

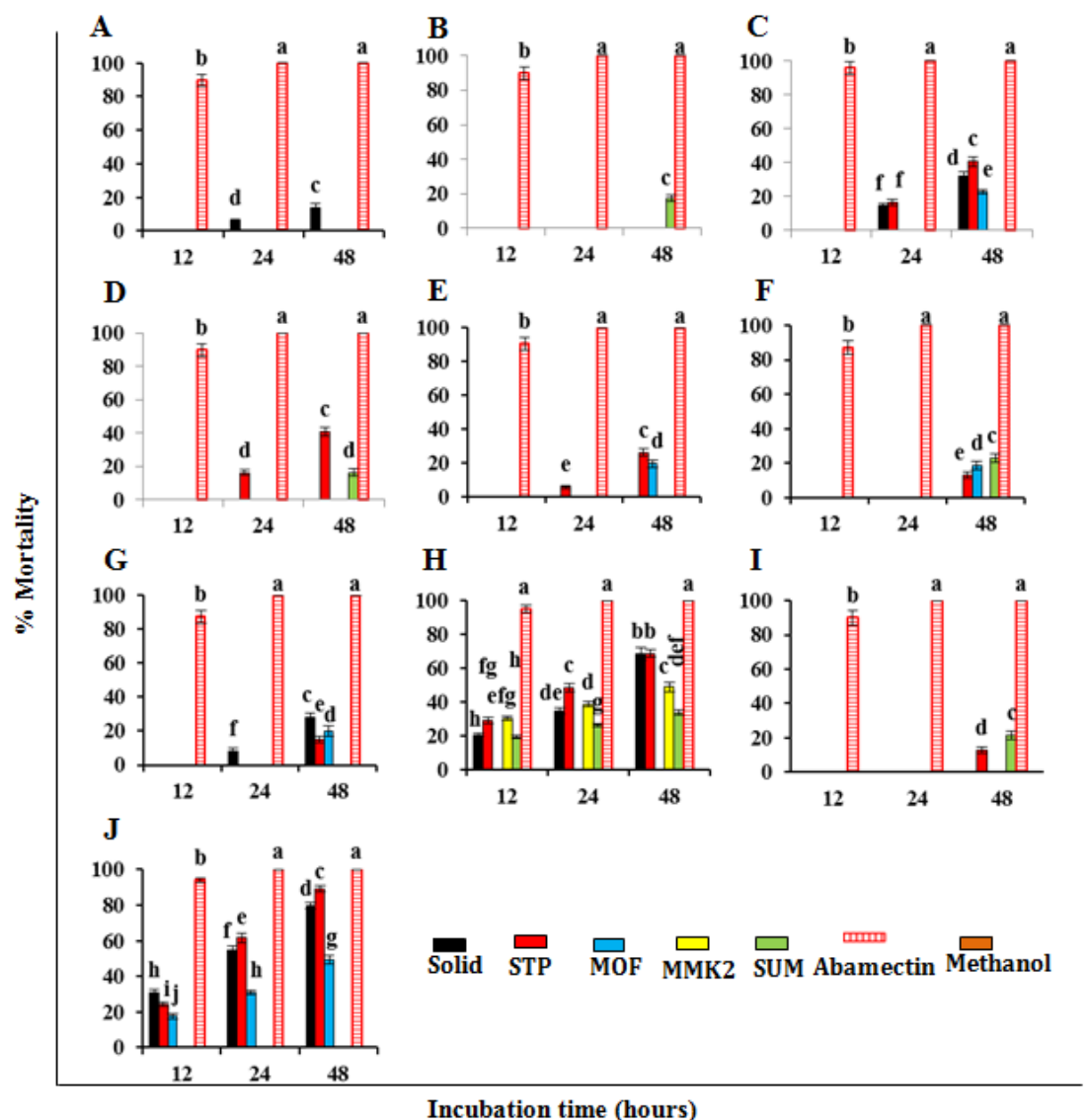

Figure 5. Effect of SMs of Trichoderma spp. obtained on different growth media on M. incognita juveniles (J2s) mortality of M. incognita. Values are the mean of three replicates. (A) T. pseudoharzianum (T113); (B) T. koningiopsis (T84); (C) T. asperelloides (T136); (D) T. pseudoharzianum (T129); (E) T. pseudoharzianum (T160); (F) T. afroharzianum (32233); (G) T. acitrinoviride (T130); (H) T. hamatum (T21); (I) T. afroharzianum (T52); (J) T. viridae. The bar represents the mean with standard deviation. Missing columns for some treatments indicated their $0.0 \%$ mortality (or no activity). Treatments having similar lettering on the bar chart show no significant $(p \geq 0.05)$ difference according to Fisher's protected LSD test. 


\subsection{Morphological Variations of M. incognita J2 under the Influence of SMs}

For the observation of morphological variations of $M$. incognita J2 under the influence of SMs, the results of T. viridae SMs (most effective) are presented in Figure 6. Microscopic observation indicated that the most effective SMs (T. viridae on STP and solid media) probably infected and destroyed internal organs, resulting in straightened and stiffened body shape (Figure 6B,C); similar observations were also recorded for positive control (Abamectin) (Figure 6A). In comparison, the exposure to T. viridae SMs obtained on MOF media showing lower effectiveness caused relatively less straightness and stiffness of the body (Figure 6D) while treatment of J2s with MMK2, SuM media, methanol and negative control, having no effect on J2s mortality, did not induce such morphological changes and the nematodes possessed a natural posture (Figure 6E-H).

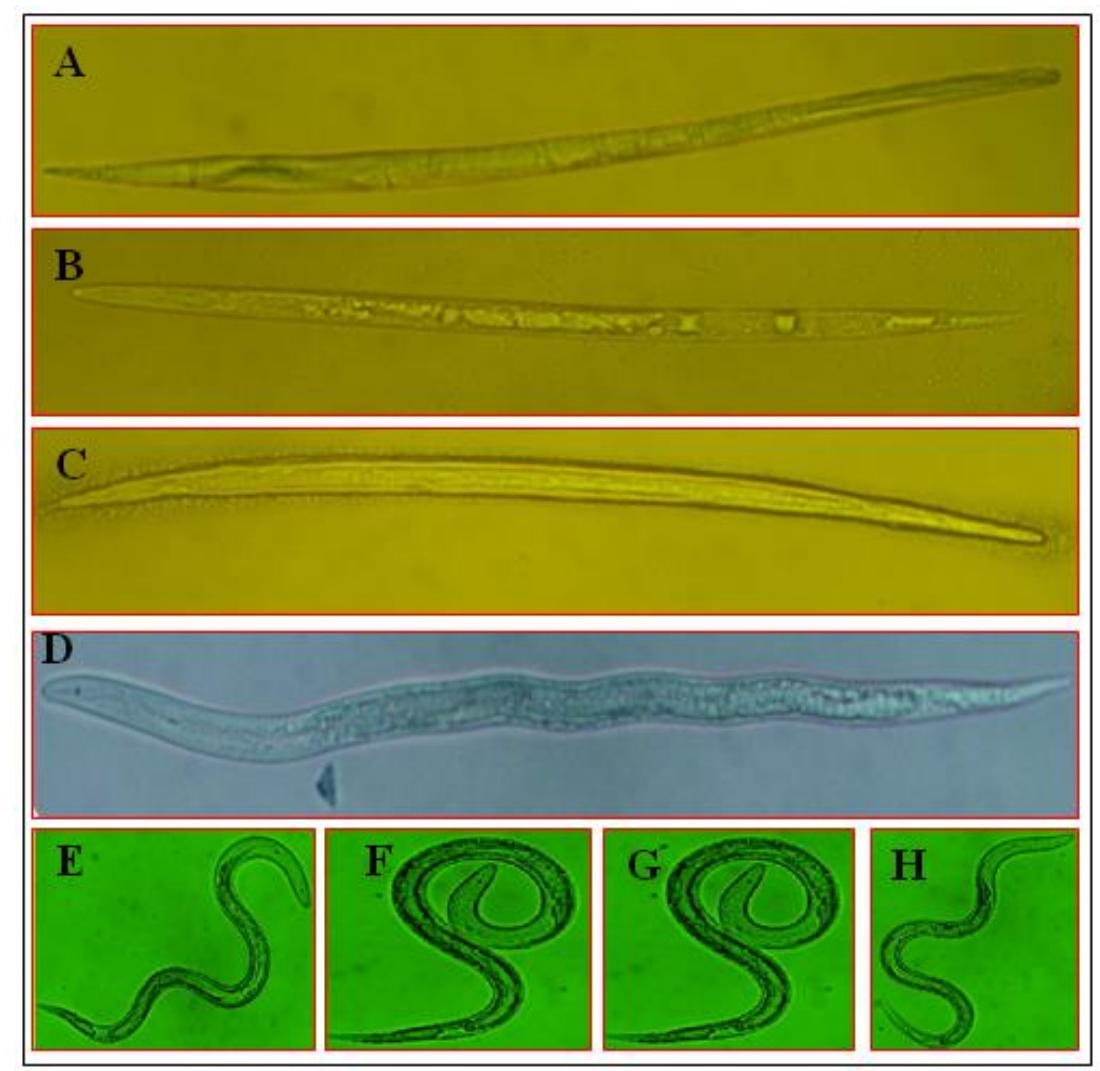

Figure 6. Morphological variations in M. incognita J2s treated with SMs of T. viridae obtained on different growth media. (A) Abamectin (positive control); (B) STP; (C) Solid; (D) MOF; (E) MMK2; (F) SuM; (G) methanol; (H) water (negative control). Bar $=300 \mu \mathrm{m}$.

\section{Discussion}

Plant pathogens cause catastrophic loss in different crops and are becoming increasingly serious threats to global food security. Huge genetic diversity, survival capacity in various environments and wide host range make them difficult to control. Therefore, an integrated approach combining host plant resistance and cultural and biological control measures seems effective. Although excellent attempts have been made in the management of plant pathogens, still there is great opportunity to contribute to this problem by finding a stable solution. Different agronomical, biochemical, chemical, cultural and biotechnological approaches have been utilized in addressing the problem of plant pathogens with different levels of success. Management of plant pathogens through bioactive secondary metabolites of bio control agents have been reported as a potential environmental and consumer-friendly approach [23]. Scientists diverted towards fungi because of their diversity in metabolites for the source of natural products that can be used effectively for the management of pathogenic microorganisms. Fungi are 
known to play an important role in biotechnology applications and their SMs have recently been used as effective biological pesticides [49]. Most of the antimicrobial metabolites are mainly derived from soil-borne fungi and these microorganisms are less explored [50]. Analysis of antimicrobial activity of these metabolites against pathogens can be employed as a simple and efficient screening tool and could be used to isolate potentially useful strains and to further identify their bioactive agents [51]. This work investigated the antimicrobial potential of Trichoderma SMs obtained on different growth media against plant pathogenic bacteria and parasitic nematode.

The results of our study indicated that SMs secreted by different Trichoderma spp. have the potential to inhibit the growth of two economically important plant pathogenic bacteria, $R$. solanacearum and $X$. compestris. Different Trichoderma species have also been reported previously for the suppression of phytopathogenic bacteria [52]. Among other mechanisms adopted by Trichoderma spp., the production of various bioactive SMs is of great importance [53]. Results showed that all of the ten Trichoderma strains are not producing bioactive secondary metabolites against $R$. solanacearum and $X$. compestris. SMs of some strains showed higher activity, some showed lower activity, while others did not affect the growth of bacteria at all. Significantly higher anti-bacterial activity was achieved by the application of SMs obtained from strains belonging to T. pseudoharzianum sp. and T. asperelloides sp. This is because the production of bioactive SMs depends on strains and species of the fungal agent. It is reported that different Trichoderma isolates are not effective equally against pathogens in in vivo and in vitro conditions [54]. During our study, significant zones of inhibition were observed. These growth-free zones are possibly because of the presence of different anti-bacterial compounds present in Trichoderma metabolites. Various anti-bacterial compounds were reported previously from Trichoderma SMs. For example, T. harzianum controlled Clavibacter michiganensis subsp. michiganensis by producing Lysosime [55]. T. harzianum T23 prevented growth of Erwinia amylovora and C. michiganensis in vitro by producing viridiofungin A (VFA) [56]. Different peptaibols such as Trichokonin VI, VII and AVIII were identified in Trichoderma spp., which are the cause of the suppression of bacterial growth [54].

Bio-active compounds damage bacterial cells by different mechanisms. Alkaloids may inhibit important enzymes or act as DNA-intercalating agents [57]. Some flavonoids coagulate soluble bacterial cell proteins, including important enzymes, by making complexes with them [58]. Others are responsible for membrane disruption [59] and inhibition of cell wall and nucleic acid synthesis [60,61]. Lysosime affects bacterial cell walls and the cell membrane, leading to membrane disruption and the release of intracellular contents and consequent bacterial cell death [62]. These mechanisms of action are consistent with our SEM studies. The micrographs show clear morphological changes that occurred as a result of treatment of the bacterial cells with SMs. The treated cells, in comparison to untreated cells, seemed to be severely damaged. Their cell walls were broken, their cell membranes were disrupted, and cell contents leaked out.

The ability to produce antibiotics is dependent on the microorganism, environment ( $\mathrm{pH}$ and temperature) and substrate. Presence of proper medium to produce bioactive compounds is necessary because it satisfies the needs of metabolite production [63]. Our results indicated that different growth media have significant roles in the production of antibacterial and nematicidal SMs. SMs obtained on different growth media have different effects in term of bacterial growth inhibition and nematicidal activity. The SMs having the highest antibacterial activity were produced by Trichoderma spp. on wheat solid media. Different scientists have also evaluated different growth media for optimizing the production of antimicrobial SMs by the fungal spp. It was reported that fungal extracts, which are prepared by using different growth media, exhibited different inhibition zones against many phytopathogenic bacteria [64,65]. Similarly, another study evaluation of different growth media revealed that growth medium's nutrient composition highly affects SMs [66]. Anti-bacterial activity can be improved by nutrient composition of media [67]. It has been recommended that that particular growth medium may result in producing a greater concentration of many bioactive compounds that may improve the activity [68]. 
Among all the studied Trichoderma spp., only SMs produced by T. virens showed significantly strong nematicidal activity causing the highest egg hatch inhibition and juvenile death. The production and bioactivity of nematicidal SMs depends on growth media, such as those metabolites obtained on STP and wheat solid media that showed higher activity. These results are in agreement with previous reports, such as when filtrates from T. virens were evaluated against $M$. incognita and it was found that the medium used for culturing the microbes affected the production of bioactive compounds [69]. In another study it was demonstrated that the bioactivity of cultural filtrates from $T$. virens against $M$. incognita depends on growth media [70], and potential biocontrol of T. virens against $M$. incognita has been achieved [71]. The bioactivity of SMs against $M$. incognita could be attributed to the nematicidal compounds. Several nematicidal compounds have been isolated from Trichoderma spp., such as acetic acid that was identified as the nematicidal principle in the culture filtrate of T. longibrachiatum [72], and Glio-toxin that has been isolated from a large number of fungi including a strain of $T$. virens which showed nematicidal activity [73]. A peptide cyclosporin A possessing nematicidal activity against M. incognita was obtained from T. polysporum [74]. Mortality of M. incognita J2s can also be explained on the basis of disintegration of nematode tissues. In previous studies, it was reported that application of SMs against $M$. incognita J2s resulted in the disintegration of internal tissue of the nematodes that eventually caused death $[75,76]$.

The crude extracts of Trichoderma may contain a variety of bioactive SMs that can be used for the management of $R$. solanacearum and $M$. incognita. Our findings help in the selection of the right candidates in order to study them in greater depth for the identification of bioactive molecules of industrial interest or in commercial formulations of products for biological control of $R$. solanacearum and M. incognita. In the context of facing the increasing demand of agriculture for ecologically compatible alternatives for the management of plant diseases, we showed the potential of Trichoderma spp. for the production of broad-spectrum bioactive metabolites against plant pathogens.

\section{Conclusions}

This study concludes that SMs from Trichoderma spp. significantly inhibited the bacterial growth and damaged the bacterial cells of $R$. solanacearum. They caused significant J2s mortality and inhibition in egg hatching of M. incognita. The bioactivity of SMs from Trichoderma spp. could increase their potential application in the biological control of plant diseases. Trichoderma spp. can be used as a potential source for the isolation of bioactive SMs against $R$. solanacearum and M. incognita. Utilization of these secondary metabolites could act as an effective, non-chemical and eco-friendly disease management tool against $R$. solanacearum, $M$. incognita and other plant pathogens.

Supplementary Materials: The following are available online at http://www.mdpi.com/2076-2607/8/3/401/s1. Table S1. Composition of five growth media used for the production of secondary metabolites.

Author Contributions: Y.L., Y.Y. and B.X. conceptualized the experiment, analyzed data and critically reviewed the manuscript for intellectual content. R.A.A.K. and S.N. performed the experiment and prepared the original draft. Z.M. and J.L. collected the data and prepared the figures. All authors have read and agreed to the published version of the manuscript.

Funding: This work was supported in part by grants from Central Public-interest Scientific Institution Basal Research Fund IVF-BRF2019012 to Y.L. and Y2017JC28 to B.X., National Key R\&D Program of China 2018YFD0201200 to Y.L., National Natural Science Foundation of China (NSFC) grants 31772214 to Y.Y.

Conflicts of Interest: The authors declare that they have no conflicts of interest.

\section{References}

1. Sabat, J.; Gupta, N. Development of modified medium for the enhancement in antifungal activity of P. steckii (MF1 Mangrove Fungi) against Verticillium Wilt pathogenic fungi of rose. Braz. Arch. Boil. Technol. 2009, 52, 809-818. [CrossRef]

2. Jones, J.T.; Haegeman, A.; Danchin, E.G.; Gaur, H.S.; Helder, J.; Jones, M.G. Top 10 plant-parasitic nematodes in molecular plant pathology. Mol. Plant Pathol. 2013, 14, 946-961. [CrossRef] 
3. Strange, R.N.; Scott, P.R. Plant disease: A threat to global food security. Annu. Rev. Phytopathol. 2005, 43, 83-116. [CrossRef] [PubMed]

4. Considine, D.M.; Considine, G.D. Foods and Food Production Encyclopedia; Springer: New York, NY, USA, 1995.

5. Mansfield, J.; Genin, S.; Magori, S.; Citovsky, V.; Sriariyanum, M.; Ronald, P. Top 10 plantpathogenic bacteria in molecular plantpathology. Mol. Plant Pathol. 2012, 13, 614-629. [CrossRef] [PubMed]

6. Scherf, J.M.; Milling, A.; Allen, C. Moderate temperature fluctuations rapidly reduce the viability of Ralstonia solanacearum race 3, biovar 2, in infected geranium, tomato, and potato plants. Appl. Environ. Microbiol. 2010, 76, 7061-7067. [CrossRef] [PubMed]

7. Jones, J.B.; Lacy, G.H.; Bouzar, H.; Minsavage, G.V.; Stall, R.E.; Schaad, N.W. Bacterialspot-worldwide distribution, importance and review. Acta Hortic. 2005, 695, 27-34. [CrossRef]

8. Camesano, T.A. Nanotechnology to Aid Chemical and Biological Defense; Springer: New York, NY, USA, 2015.

9. Nicol, J.M.; Turner, S.J.; Coyne, D.L.; den Nijs, L.; Hockland, S.; Tahna Maafi, Z. Current nematode threats to world agriculture. In Genomics and Molecular Genetics of Plant Nematode Interactions; Jones, J., Gheysen, G., Fenoll, C., Eds.; Springer: Dordrecht, The Netherlands, 2011; pp. 21-43. [CrossRef]

10. McCarter, J.P. Nematology: Terra incognita no more. Nat. Biotechnol. 2008, 26, 882-884. [CrossRef] [PubMed]

11. Jang, J.Y.; Choi, Y.H.; Shin, T.S.; Kim, T.H.; Shin, K.S.; Park, H.W. Biological Control of Meloidogyne incognita by Aspergillus niger F22 Producing Oxalic Acid. PLoS ONE 2016, 11, e156230. [CrossRef]

12. Goode, M.J.; Sasser, M. Prevention-the key to controlling bacterial spot and bacterial speck of tomato. Plant Dis. 1980, 64, 831-834. [CrossRef]

13. Mariano, R.L.R.; Silveira, N.S.S.; Michereff, S.J. Bacterial wilt in Brazil: Current status and control methods. In Bacterial Wilt Disease; Prior, P., Allen, C., Elphinstone, J., Eds.; Springer: Berlin, Germany, 1998; pp. 386-393. [CrossRef]

14. Yuliar, N.Y.A.; Toyota, K. Recent trends in control methods for bacterial wilt diseases caused by Ralstonia solanacearum. Microbes Environ. 2015, 30,1-11. [CrossRef]

15. Wang, J.F.; Olivier, J.; Thoquet, P.; Mangin, B.; Sauviac, L.; Grimsley, N.H. Resistance of tomato line Hawaii7996 to Ralstonia solanacearum Pss4 in Taiwan is controlled mainly by amajor strain-specific locus. Mol. Plant Microbe Interact. 2000, 13, 6-13. [CrossRef] [PubMed]

16. Ritchie, D.F.; Dittapongpitch, V. Copper-andstreptomycin-resistant strains and host differentiated races of Xanthomonas campestris pv. vesicatoria in North Carolina. Plant Dis. 1991, 75, 733-736. [CrossRef]

17. McDonald, B.A.; Linde, C. Pathogen population genetics, evolutionary potential, and durable resistance. Annu. Rev. Phytopathol. 2002, 40, 349-379. [CrossRef] [PubMed]

18. Trudqill, D.L.; Blok, V.C. Apomictic, polyphagous root-knot nematodes: Exceptionally successful and damaging biotrophic root pathogens. Annu. Rev. Phytopathol. 2001, 39, 53-77. [CrossRef] [PubMed]

19. Manzanilla-Lopez, R.H.; Kenneth, E.; Bridge, J. Plant diseases caused by nematodes. In Nematology: Advanced and Perspectives. Nematode Management and Utilization; Chen, Z.X., Chen, S.Y., Dickson, D.W., Eds.; CAB International: Wallingford, UK, 2004; Volume II, pp. 637-716.

20. Ntalli, N.G.; Caboni, P. Botanical nematicides: A review. J. Agri. Food Chem. 2012, 60, 9929-9940. [CrossRef] [PubMed]

21. Fuller, V.L.; Lilley, C.J. Urwin PE. Nematode resistance. New Phytologist. 2008, 180, 27-44. [CrossRef] [PubMed]

22. Organisation for Economic Co-operation and Development (OECD). Agricultural Policies in OECD Countries: Monitoring and Evaluation; OECD: Paris, France, 2001.

23. Hyde, K.D.; Soytong, K. The fungal endophyte dilemma. Fungal Divers. 2008, 33, e173.

24. Hoffmeister, D.; Keller, N.P. Natural products of filamentous fungi: Enzymes, genes, and their regulation. Nat. Prod. Rep. 2007, 24, 393-416. [CrossRef]

25. Keller, J.M.; Mcclellan-green, P.D.; Kucklick, J.R.; Keil, D.E.; Peden-adams, M.M. Effects of organochlorine contaminants on loggerhead sea turtle immunity: Comparison of a correlative field study and in vitro exposure experiments. Environ. Health Perspect. 2005, 114, 70-76. [CrossRef]

26. Osbourn, A. Gene clusters for secondary metabolic pathways: An emerging theme in plant biology. Plant Physiol. 2010, 1, 154. [CrossRef]

27. Daoubi, M.; Pinedo-rivilla, C.; Rubio, M.B.; Hermosa, R.; Monte, E.; Aleu, J.; Collado, I.G. Hemisynthesis and absolute configuration of novel 6-pentyl-2H-pyran-2-one derivatives from Trichoderma spp. Tetrahedron 2009, 65, 4834-4840. [CrossRef] 
28. Meyer, V. Genetic engineering of filamentous fungi-Progress, obstacles and future trends. Biotechnol. Adv. 2008, 26, 177-185. [CrossRef]

29. Harman, G.E.; Howell, C.R.; Viterbo, A.; Chet, I.; Lorito, M. Trichoderma species-opportunistic avirulent plant symbionts. Nat. Rev. Microbiol. 2004, 2, 43-56. [CrossRef] [PubMed]

30. Ming, Q.; Han, T.; Li, W.; Zhang, Q.; Zhang, H.; Zheng, C. Tanshinone II A and tanshinone I production by Trichoderma atroviride D16, an endophytic fungus in Salvia miltiorrhiza. Phytomedicine 2012, 19, 330-333. [CrossRef] [PubMed]

31. Monte, E. Understanding Trichoderma: Between agricultural biotechnology and microbial ecology. Int. Microbiol. 2001, 4, 1-4. [PubMed]

32. Vizcaino, J.A.; Sanz, L.; Cardoza, R.E.; Monte, E.; Gutierrez, S. Detection of putative peptide synthetase genes in Trichoderma species. Application of this method to the cloning of a gene from T. harzianum CECT 2413. FEMS Microbiol. Let. 2005, 244, 139-148. [CrossRef]

33. Vinale, F.; Sivasithamparam, K.; Ghisalberti, E.L.; Woo, S.L.; Nigro, M.; Marra, R. Trichoderma secondary metabolites active on plants and fungal pathogens. Open Mycol. J. 2008, 8, 127-139. [CrossRef]

34. Sivasithamparam, K.; Ghisalberti, E.L. Secondary metabolism in Trichoderma and Gliocladium. In Trichoderma and Gliocladium. Vol. 1. Basic Biology, Taxonomy and Genetics; Kubicek, C.P., Harman, G.E., Eds.; Taylor \& Francis: London, UK, 1998; pp. 139-191.

35. Luckner, M. Secondary Metabolism in Microorganisms, Plants and Animals, 3rd ed.; Springer: Berlin, Germany, 1990.

36. Carvalho Filho, M.R.; Menezes, J.E.; Mello, S.C.M.; Santos, R.P. Avaliação de Isolados de Trichoderma No Controle da Mancha Foliar do Eucalipto in Vitro e Quanto a Esporulação Em Dois Substratos Sólidos. Bol. Pesqui. Desenvolv. Brasília 2008, 225, 21.

37. Khalili, E.; Sadravi, M.; Naeimi, S.; Khosravi, V. Biological control of rice brown spot with native isolates of three Trichoderma. Braz. J. Microbiol. 2012, 43, 297-305. [CrossRef]

38. Jeyaseelan, E.C.; Tharmila, S.; Niranjan, K. Antagonistic activity of Trichoderma spp. and Bacillus spp. against Pythium aphanidermatum isolated from tomato damping off. Arch. Appl. Sci. Res. 2014, 4, 1623-1627.

39. Barari, H. Biocontrol of tomato Fusarium wilt by Trichoderma species under in vitro and in vivo conditions. Cercet. Agron. Mold. 2016, 49, 91-98. [CrossRef]

40. Becker, J.O.; Zavaleta-Mejia, E.; Colbert, S.F.; Schroth, M.N.; Weinhold, A.R.; Hancock, J.G.; Van Gundy, S.D. Effects of rhizobacteria on root-knot nematodes and gall formation. Phytopathology 1988, 78, 1466-1469. [CrossRef]

41. Vizcaino, A.; Sanz, L.; Basilio, A. Screening of antimicrobial activities in Trichoderma isolates representing three Trichoderma sections. Mycol. Res. 2006, 109, 1397-1406. [CrossRef] [PubMed]

42. Hussey, R.S.; Barker, K.R. Comparison of methods of collecting inocula of Meloidogyne spp., including a new technique. Plant Dis. Rep. 1973, 57, 1025-1028.

43. Tong, X.; Shen, X.Y.; Hou, C.L. Antimicrobial Activity of Fungal Endophytes from Vaccinium dunalianum Var. Urophyllum. Sains Malaysiana. 2018, 47, 1685-1692. [CrossRef]

44. Hwa, S.; Ryung, Y.; Sung, S.Y.; Jae, S.S.; Jo, M.K. Detection and Antibacterial Activity of a Bacteriocin Produced by Lactobacillus plantarum. Food Sci. Biotechnol. 2001, 10, 461-467.

45. Kamonwannasit, S.; Nantapong, N.; Kumkrai, P.; Luecha, P.; Kupittayanant, S.; Chudapongse, N. Antibacterial Activity of Aqularia crassna Leaf Extract against Staphylococcus epidermis by Disruption of Cell Wall. Ann. Clin. Microbiol. Antimicrob. 2013, 12, 20. [CrossRef]

46. Gomez, K.A.; Gomez, A.A. Statistical Procedures for Agricultural Research; John Wiley and Sons: New York, NY, USA, 1984.

47. Verdejo-Lucas, S.; Cortada, L.; Sorribas, F.J.; Ornat, C. Selection of virulent populations of Meloidogyne javanica by repeated cultivation of Mi resistance gene tomato rootstocks under field conditions. Plant Pathol. 2009, 58, 990-998. [CrossRef]

48. Abbott, W.S. A method of computing the effectiveness of an insecticide. J. Am. Mosq. Control Assoc. 1987, 3, 302-303. [CrossRef]

49. Pramila, T.; Dubey, N.K. Exploitation of natural products as an alternative strategy to control postharvest fungal rotting of fruit and vegetables. Postharvest Biol. Technol. 2004, 32, 235-245. [CrossRef]

50. Hara-Kishore, K.; Misra, S.; Chandra, D.R.; Prakash, K.V.V.R.; Murty, U.S. Antimicrobial efficacy of secondary metabolites from Glomerella cingulata. Braz. J. Microbiol. 2007, 38, 150-155. [CrossRef] 
51. Dos Santos, I.P.; Silva, L.C.N.; Silva, M.V.; Araujo, J.M.; Cavalcanti, M.S.; Lima, V.L.M. Antibacterial activity of endophytic fungi from leaves of Indigofera suffruticosa Miller. (Fabaceae). Front. Microbiol. 2015, 6, 350. [CrossRef] [PubMed]

52. Avis, T.J.; Gacel, V.; Antoun, H.; Tweddell, R.J. Multifaceted beneficial effects of rhizosphere microorganisms on plant health and productivity. Soil Biol. Biochem. 2008, 40, 1733-1740. [CrossRef]

53. Gal-hemed, I.; Atanasova, I.; Komo-zelazowsla, M.; Druzhinina, I.S.; Viterbo, A.; Yarden, O. Marine isolates of Trichoderma spp. as potential halotolerant agents of biologicla control for Arid-zone agriculture. Appl. Environ. Microbiol. 2011, 77, 5100-5109. [CrossRef]

54. Xiao-yan, S.; Qing-tao, S.; Shu-tao, X.; Xiu-lan, C.; Cai-yan, S.; Yu-zhong, Z. Broad-spectrum antimicrobial activity and high stability of Trichokonins from Trichoderma koningii SMF2 against plant pathogens. FEMS. Microbiol. Let. 2006, 260, 119-125. [CrossRef] [PubMed]

55. Utkhede, R.; Koch, C. Biological treatments to control bacterial canker of greenhouse tomatoes. Biocontrol 2004, 49, 305-313. [CrossRef]

56. El-Hasan, A.; Walker, F.; Schöne, J.; Buchenauer, H. Detection of viridiofungin A and another antifungal metabolites excreted by Trichoderma harzianum active against different plant pathogens. Eur. J. Plant Pathol. 2009, 124, 457-470. [CrossRef]

57. Tanaka, J.C.A.; da Silva, C.C.; de Oliveira, A.J.B.; Nakamura, C.V.; Dias, B.P. Antibacterial activity of indole alkaloids from Aspidosperma ramiflorum. Braz. J. Med. Biol. Res. 2006, 39, 387-391. [CrossRef]

58. Al-Obaidi, O. Studies on antibacterial and anticancer activity of Nerium oleander extracts. Eur. Chem. Bull. 2014, 3, 259-262. [CrossRef]

59. Tsuchiya, H. Memberane interactions of phytochemicals as their molecular mechanism applicable to the discovery of drug leads from plants. Molecules 2015, 20, 18923-18966. [CrossRef]

60. Plaper, A.; Golob, M.; Hafner, I.; Oblak, M.; Solmajer, T.; Jerala, R. Characterization of quercetin binding site on DNA gyrase. Biochem. Biophy. Res. Commun. 2003, 306, 530-536. [CrossRef]

61. Zhang, L.; Kong, Y.; Wu, D.; Zhang, H.; Wu, J.; Chen, J.; Ding, J.; Hu, L.; Jiang, H.; Shen, X. Three flavonoids targeting the beta-hydroxyacyl-acyl carrier protein dehydratase from Helicobacter pylori: Crystal structure characterization with enzymatic inhibition assay. Protein Sci. 2008, 17, 1971-1978. [CrossRef] [PubMed]

62. Saito, H.; Sakakibara, Y.; Sakata, A.; Kurashige, R.; Murakami, D.; Kageshima, H.; Saito, A.; Miyazaki, Y. Antibacterial activity of lysozyme-chitosan oligosaccharide conjugates (LYZOX) against Pseudomonas aeruginosa, Acinetobacter baumannii and Methicillin-resistant Staphylococcus aureus. PLoS ONE 2019, 14, e0217504. [CrossRef] [PubMed]

63. Stanbury, P.F.; Whitaker, A.; Hall, S.J. Principles of Fermentation Technology; Elsevier: London, UK, 1997.

64. Rizk, M.; Abdel-rahman, T.; Metwally, H. Factors Affecting Growth and Antifungal Activity of Some Streptomyces Species against Candida albicans. J. Food Agric. Environ. 2007, 5, 446-449.

65. El-Tayeb, O.M.; Hussein, M.M.N.; Salama, A.A.; El-Sedawy, H.F. Optimization of industrial production of rifamycin B by Amycolatopsis mediterranei. II. The role of gene amplification and physiological factors in productivity in shake flasks. Afr. J. Biotechnol. 2004, 3, 273-280. [CrossRef]

66. Slininger, P.J.; Shea-wilbur, M.A. Liquid culture $\mathrm{pH}$, temperature carbon and nitrogen source regulate phenazine productivity of the take all biocontrol agent Pseudomonas fluorescence. Appl. Microbial. Biotechnol. 1995, 37, 388-392. [CrossRef]

67. Ramos, H.P.; Said, S. Modulation of biological activities produced by an endophytic fungus under different culture conditions. Adv. Biosci. Biotech. 2011, 2, 443-449. [CrossRef]

68. Vijaykumar, S.J.; Sasidharannair, N.K.; Nambision, B.; Mohandas, C. Optimization of Media and Temperature for Enhanced Antimicrobial Production by Bacteria Associated with Rhabitis sp. Iran. J. Microbial. 2013, 5, 136-141.

69. Massoud, S.; Meyer, S.L.; Roberts, D.; Chitwood, D. Evaluation of Trichoderma virens and Burkholderia cepacia for antagonistic activity against root-knot nematode, Meloidogyne incognita. Nematology 2000, 2, 871-879. [CrossRef]

70. Roberts, D.P.; Lumsden, R.D. Effect of extracellular metabolites from Gliocladium virens on germination of sporangia and mycelial growth of Pythium ultimum. Phytopathology 1990, 80, 461-465. [CrossRef]

71. Meyer, S.L.F.; Roberts, D.P.; Chitwood, D.J.; Carta, L.K.; Lumsden, R.D.; Mao, W. Application of Burkholderia cepacia and Trichoderma virens, alone and in Combinations, against Meloidogyne incognita on Bell Pepper. Nematropica 2001, 31, 75-86. 
72. Djian, C.; Pijarouvski, L.; Ponchet, M.; Arpin, N. Acetic Acid, a Selective Nematicidal Metabolite from Culture Filtrate of Paecilomyces lilacinus (Thom) Samsan and Trichoderma longibrachiatum Rifai. Nematologica 1991, 37, 101-110.

73. Anitha, R.; Murugesan, K. Production of gliotoxin on natural substrates by Trichoderma virens. J. Basic Microbiol. 2005, 45, 12-19. [CrossRef] [PubMed]

74. Li, G.H.; Zhang, K.Q.; Xu, J.P.; Dong, J.Y.; Liu, Y.J. Nematicidal substances from fungi. Rec. Pat. Biotechnol. 2007, 1, 212-233. [CrossRef]

75. Schuster, R.P.; Sikora, R.A.; Amin, N. Potential of endophytic fungi for the biological control of plant parasitic nematodes. Commun. Appl. Biol. Sci. 1995, 60, 1047-1052.

76. Hallmann, J.; Quadt-Hallmann, A.; Miller, W.G.; Sikora, R.A.; Lindow, S.E. Endophyte colonization of plants by biocontrol agent Rhizobium etli G12 in relation to Meloidogyne incognita infection. Phytopathology 2001, 91, 415-422. [CrossRef]

(C) 2020 by the authors. Licensee MDPI, Basel, Switzerland. This article is an open access article distributed under the terms and conditions of the Creative Commons Attribution (CC BY) license (http://creativecommons.org/licenses/by/4.0/). 